\title{
Analysis of current trends in assessing the country's potential in international trade (on example of Peru)
}

\author{
Oleg N. Zhilkin, Wilmer Paul Chavarry Galvez \\ Peoples' Friendship University of Russia (RUDN University) \\ 6 Miklukho-Maklaya St, Moscow, 117198, Russian Federation
}

\begin{abstract}
The article discusses issues of international trade theory and current global economic trends to assess the possibility of developing the foreign economic sector in Latin America as a whole, and in particular, Peru. Using development statistics from the foreign trade sector, and considering global trends in international trade over the past decade, an attempt is made to assess the ability of Latin American countries to meet growing differentiated demand and thus specialize in advantageous sectors, allowing them to integrate into global supply chains by providing resources, goods, and services at primary, secondary, and tertiary market levels. By examining the potential of Latin American countries, there is a real possibility of creating value chains around market niches that exist in global trade and applying them to ensure that Latin American products receive international recognition. In this context, the analysis of the dynamics of trade exchange is taken as a basis for comparing Peru with other countries, since according to the IMF, in recent years, Peru is one of the countries with the highest economic growth forecast in Latin America. Peru has great potential in mining (in Ankash, Arequipa and Junin, among other places), commercial fishing (Ankash, Liberty, Piura and others), agriculture (Piura, Liberty, Ica and others), camelid breeding (vicuña, alpaca, etc., in Puno, Junin, Cuzco) and other activities. In 2018, Peru managed to raise total exports up to $\$ 47.7$ billion USD $(+7.5 \%$ from 2017), thus achieving a historic record for Peruvian exports. This growth is explained by noticeable growth in the non-traditional sector, which reached $\$ 13.2$ billion $(+12.6 \%$ from 2017). The present study uses the theory of comparative advantage to quantify product competitiveness based on global comparison, which helps indicate how to move towards higher levels of specialization in the production and export structure. To analyze international trade data, we used indicators such as the Balance of Trade and the Balassa Index, which allowed us to determine a list of thirty products, of which twenty (traditional and non-traditional) showed a steady increase in exports, and the other ten, mainly non-traditional, despite being lower in ranking, have greater potential for further growth.
\end{abstract}

Keywords: international trade, comparative advantages, exports, Latin America

\section{Introduction}

Despite significant macroeconomic gains recorded over the past decade, the economy still has not broken out of its middle-income trap or significantly elevated its median income range. This result is due to Peruvians owning only a small share of domestic economic growth, and on the industry's continued dependence

(C) Zhilkin O.N., Chavarry Galvez W.P., 2020

(c) This work is licensed under a Creative Commons Attribution 4.0 International License https://creativecommons.org/licenses/by/4.0/ 
on the state of the natural resources market. This is due to the fact that the Peruvian economy is open, which means that it is highly susceptible to fluctuations in the external environment, such as the 2014 economic

Based on the above, the implementation of structural reforms related to further diversification of the economy in more promising sectors will lead to an increase in new highly qualified jobs and an increase in value-added exports, which will reduce dependence on external demand for raw materials (Lauterbach, 2015).

In this context, and given the current composition of the Peruvian export basket, this study seeks to identify export products with potential for international trade. To do this, the study considers two important elements. Firstly, it analyzes those types of products in which the country have gained comparative advantages in recent years and which would benefit from "an extra push", having strengthened their production potential to meet rising global demand. Evaluated secondly are products that have the smallest share in the export basket, but which can continue to grow and gain market dominance over time.

In development of this research, the Balance of Trade (BOT) and the Balassa Index (IB) methodology was applied, which is based on various theories of comparative advantage that have emerged over the years. As a result, a study was conducted on the basis of thirty products, as mentioned above.

In particular, Peru has leading products in the export of goods at the national level, such as copper and gold ores; agricultural products such as avocados, asparagus, mangos, cacao; textile products such as fine vicuña and alpaca wool, among others. However, the export basket is wider and leaves room for international trade in other products with comparative advantages, such as jewelry, precious or semiprecious stones, agricultural seeds, styrene-polymer waste and other products that offer hidden comparative advantages.

\section{Literature review: analysis of the comparative advantage model}

Potential opportunities are those opportunities that a country has for inclusion in global value chains and for exploiting niche markets in various geographical spaces (national, regional or global) to positively affect economic growth, employment and diversification of production. For this, it is necessary to identify those goods in which the country has comparative advantages in order to ensure profitability in producing those goods, and in turn provide favorable positioning in international trade. In this regard, according to the Organisation for Economic Co-operation and Development (OECD), competitiveness is an indicator of the country's advantages or disadvantages in selling its products in international markets.

In addition, the OECD (2013) states that most products and a growing portion of services are currently produced worldwide, in various companies and countries that specialize in specific functions and tasks that together make up the global value chain.

Therefore, specialization in international trade is a factor allowing some countries to be more competitive than others; in this regard, the principle of comparative advantage states that in order to be profitable, each country must specialize in the production and export of goods that it can produce at relatively low prices. 
According to P. Krugman and M.J. Melitz (2014), a country can capitalize on its differences and specialize in what it does relatively well or for which it has some advantage different from other economies. In this regard, R. Gonzalez (Gonzalez, 2017) notes that countries do not specialize in the production of a single product, as theoretical models suggest, but rather profit in international trade from those products for which they have comparative advantages.

One of the questions that has often been raised in various studies is what determines that some countries grows more than others. In other words, why are some countries poorer than others? This question is not new, and, as R. Haussman (Hausmann, 2014) mentions, it is a question with which he began to be introduced into economic science in 1776, when A. Smith wrote "A Study on the Nature and Causes of the Wealth of Nations." In his work, he presents an analysis of the causes of prosperity in England, which were then examined from a different perspective by T. Malthus, studying the process of creating and accumulating wealth.

In the early nineteenth century, economist D. Ricardo developed the theory of comparative advantage in response to A. Smith's theory of absolute advantage, which states that a country should specialize in producing goods that it can produce most efficiently. D. Ricardo introduced the concept of comparative advantages of international trade, which states that countries will usually specialize in the production and export of products with a relatively lower cost of production; that is, a country will specialize in a product that has a certain advantage, not necessarily what it produces better than others.

Similarly, a country will import the products it produces least efficiently, i.e. those that incur higher production costs. Thus, A. Smith's postulate is "weakened" and priority was given to internal cost analysis. D. Ricardo explains that the concept of alternative costs is key in the analysis of relative costs.

In this regard, as noted by Gonzalez (2017), the contribution of the classical school to the theory of international trade in relation to how the model of international trade between countries should work, was developed by A. Smith and D. Ricardo, who developed the concepts of absolute advantage and comparative advantage, respectively.

According to the World Trade Organization (2018), there is a positive statistical relationship between freer trade and economic growth. Countries possess, in particular, human, industrial, natural and financial resources that they can use to produce goods and services for consumption in domestic or foreign markets. In this regard, the principle of comparative advantage means that for countries to flourish, they should focus on what they produce best, and exchange these products for those that other countries produce best.

For the WTO, one country has a comparative advantage in the production of a particular product if the opportunity costs of these products, rather than others, are lower in that economy than in another. Thus, each country will specialize in the production of those products in which it has a comparative advantage. However, the Ricardo model is a simplified model based on labor productivity and does not take into account other factors related to international trade relations. This allowed E. Heckscher and B. Olin to create a theory a few years later, in which international trade is determined by the interaction of factors other than labor, such as capital and land. 
In addition, it is important to note that D. Ricardo states in his theory that goods bring value from work, therefore, for the author, it is better to produce efficiently, meaning less use of work. Thus, the factor of labor is present in its analysis, which is an important part in the analysis of comparative advantages. Thus, the author determines that the product will have a comparative advantage if it meets the following condition:

$$
\left.\left.(\mathrm{aLx}) /(\mathrm{aLy})<\llbracket \mathrm{aL}^{\prime} \mathrm{x}\right)\right] /\left[\mathrm{aL}^{\prime} \mathrm{y} \rrbracket\right.
$$

where aLx - working factor of products in country A; aLy - working factor of product $\mathrm{Y}$ in country $\mathrm{A}$; $\mathrm{aL} \mathrm{L}^{\prime} \mathrm{x}$ - working factor of the product $\mathrm{X}$ in the country; $\mathrm{aL}^{\prime} \mathrm{y}$ - working factor of product $\mathrm{Y}$ in country $\mathrm{B}$.

If expression (1) is met, it can be argued that there are comparative advantages in the production of product $\mathrm{X}$ in country A. To carry out the above analysis, it is necessary to use interpretative tools that permit multiple variables and thus allow the analysis of a group of products and their competitive positioning in the international market. In this regard, there are several indices in the literature that make it possible to establish a link between the trade exchange of a particular region, sector, or product (González, 2017).

Similarly, Duran and Alvarez (2008) are reviewing key indicators related to trade dynamism based on data from various international trade sources, such as, inter alia, indicators of identified comparative advantages, Balassa, and Herfindahl - Hirschman's diversification/concentration, in order to understand a country's trade structure and its dynamics at the international level.

Indicators of trade dynamics reflect the export behavior of a particular product or sector, each of which represents a specific trend. For example, some measure the export trend in an absolute way, while others measure the exporting or importing trend for a particular market and/or the interest that the international market may represent for a particular sector.

In addition, Lauterbach (2015) uses the export complexity model developed by Hausmann et al. (2011) to analyze which economic sectors can be explored in Chile in search of new engines that will lead to further growth, development and positive externalities throughout Chile economy. For this, various indicators are used, such as the index of comparative advantages revealed, the distance index, the product complexity index, the index of growth in opportunities, etc., which describe production and relations between countries.

In addition, the study by Torres, Romero, and Cruz (2015) analyzes the identified comparative advantages of foreign trade between Mexico and Turkey using trade indicators related to the positioning and dynamics of foreign trade, as well as the comparative advantages between the two countries from the trade flow of goods. Having conducted an empirical study with IB, the study shows that the model of specialization and comparative advantage between Mexico and Turkey is only given in 7 of the 21 analyzed sections of the harmonized system, and are the most visible products that are contained in sections II (vegetable kingdom), VI (chemicals), VII (plastic and rubber), XIV (precious metals) and XXI (works of art, antiques).

Based on the above studies, specialization in international trade is determined by the recognition of why some countries are more competitive than others, and 
in this regard, the principle of comparative advantage states that in order to be profitable, each country must specialize in the production and export of those goods which it can produce at relatively low prices. Therefore, when countries are focused on areas where they have comparative advantages in free trade, this improves the situation around the world.

Aggregate multilateral relative Balance of Trade. As Gomez (2015) notes, the relative Balance of Trade measures a country's importing or exporting trend for a particular product, establishing a relationship between the trade balance (exports minus imports) and trade exchange (exports plus imports). So, you have the following:

$$
\mathrm{BOT} \frac{k}{i t}=\frac{X \frac{k}{i t}-M \frac{k}{i t}}{X \frac{k}{i t}-M \frac{k}{i t}}
$$

where $X_{i j}^{k}$ - total product exports to the country and in the period $T ; M_{i j}^{k}-$ total import of the product to the country in the period $T$.

It follows from expression (2) that the values of this indicator range from -1 to 1 . If it is close to -1 , it indicates that this is the product where most imports are made; while values close to 1 indicate the country's export position in a particular product. From the approach to positioning in international markets, positive values close to 1 indicate that there are comparative advantages over the estimated product.

Balassa's Index. The Balassa index measures the potential of a product to export from one country to another, relative to the importance of exporting the same country and product to the world. This is indicated as follows:

$$
\mathrm{IB}_{i j}^{k}=\frac{\frac{x_{i j}^{k}}{X T_{i j}}}{\frac{X_{i w}^{k}}{X T_{i w}}}
$$

where $X_{i j}^{k}$ - export of products $k$ carried out by country $i$ to country $j ; X T_{i j}-$ total exports from country $i$ to country $j ; X_{i w}^{k}$ - export of products $k$ carried out by country $i$ to the world $w ; X T_{i w}$ - total export of country $i$ to the world $w$.

According to this indicator, higher indicators indicate that the country has more opportunities for international trade in this product compared to the source country, and therefore it can be argued that the country has a comparative advantage in terms of sales of this product compared to the country of comparison. Since the index is compiled in comparison with another country, it is recommended to normalize the result according to Duran and Alvarez (2008) for better understanding. Below is the standard Balassa Index.

$$
\mathrm{IB}_{i j}^{k} \text { normalized }=\frac{\mathrm{IB}_{i j}^{k}-1}{\mathrm{IB}_{i j}^{k}+1}
$$

The interpretation of the indicator remains the same as its non-normalized indicator; however, having values from -1 to 1 , it can improve the comparative analy- 
sis that is done with the reference countries. Reading the indicator is interpreted in accordance with the following intervals:

$0.33<\mathrm{IB}_{i j}^{k}<1.00-$ country $i$ has an advantage;

$-0.33<\mathrm{IB}_{i j}^{k}<0.33$ - there is a tendency to trade between products;

$-1<\mathrm{IB}_{i j}^{k}<-0.33$ - country $i$ has a drawback.

In this order, BOT will determine if Peru has a comparative advantage with respect to the product being evaluated, and based on a multilateral approach, you can determine the benefits of Peru over the rest of the world with respect to a particular product. On the other hand, IB will allow a more accurate assessment of Peru's comparative advantage, since it will compare the country's advantages compared to another country and around the world. Thus, Peruvian products with great export potential will be identified.

\section{Research methods}

The methodological process developed was based on international trade information from different platforms such as Comtrade, the Peruvian Strategic Research Center, INEI (Peruvian Institute of Statistics and Informatics), World Bank, RBC Daily Business Newspaper and others. As well as studies carried out by different Russian and foreign authors, which have provided detailed access to the main data on world foreign trade as well as the analysis of international trade data. With this, it has had access to the exports and imports that Peru has made to the different destination markets during the period 2010-2018. Likewise, exports to the world of all countries were processed.

\section{Results: \\ Peru and its impact on the international market}

In recent years, Peru has entered into the process of opening trade, which allowed it to enter global markets with a wider offer of products. In this regard, when analyzing the main indicators of the trading position, it should be noted that over the past twenty years, the country has significantly increased the value of its exports. In 1997, according to Central Reserve Bank of Peru (Central Reserve Bank of Peru, 2018), Peru exported goods worth $\$ 6,825$ million to the world, while in 2017 this figure reached $\$ 44,918$ million.

The growth was impressive; in 1997, 12 non-traditional goods were registered with shipments abroad worth more than $\$ 30$ million (metal and clothing production, mainly); while in 2019 this indicator increased to 72 products, emphasizing the share of agricultural products. In 1997, the value of agricultural exports reached \$ 340 million; in 2019, this figure increased to 6341 million US dollars, according to Central Reserve Bank of Peru (2020) (see Figure 1).

The progress made by the country in terms of new exported goods and target markets is based on the wide network of trade agreements reached by Peru, such as free trade agreements with the United States, the European Union, China, Mexico and Chile, in particular, which allowed preferential access to Peruvian products, mostly not traditional. In this regard, according to MINCETUR (2017), 89\% of Peruvian exports were covered in 2017 by international trade agreements; however, diversification is an unresolved topic for launching other engines for the economy. 


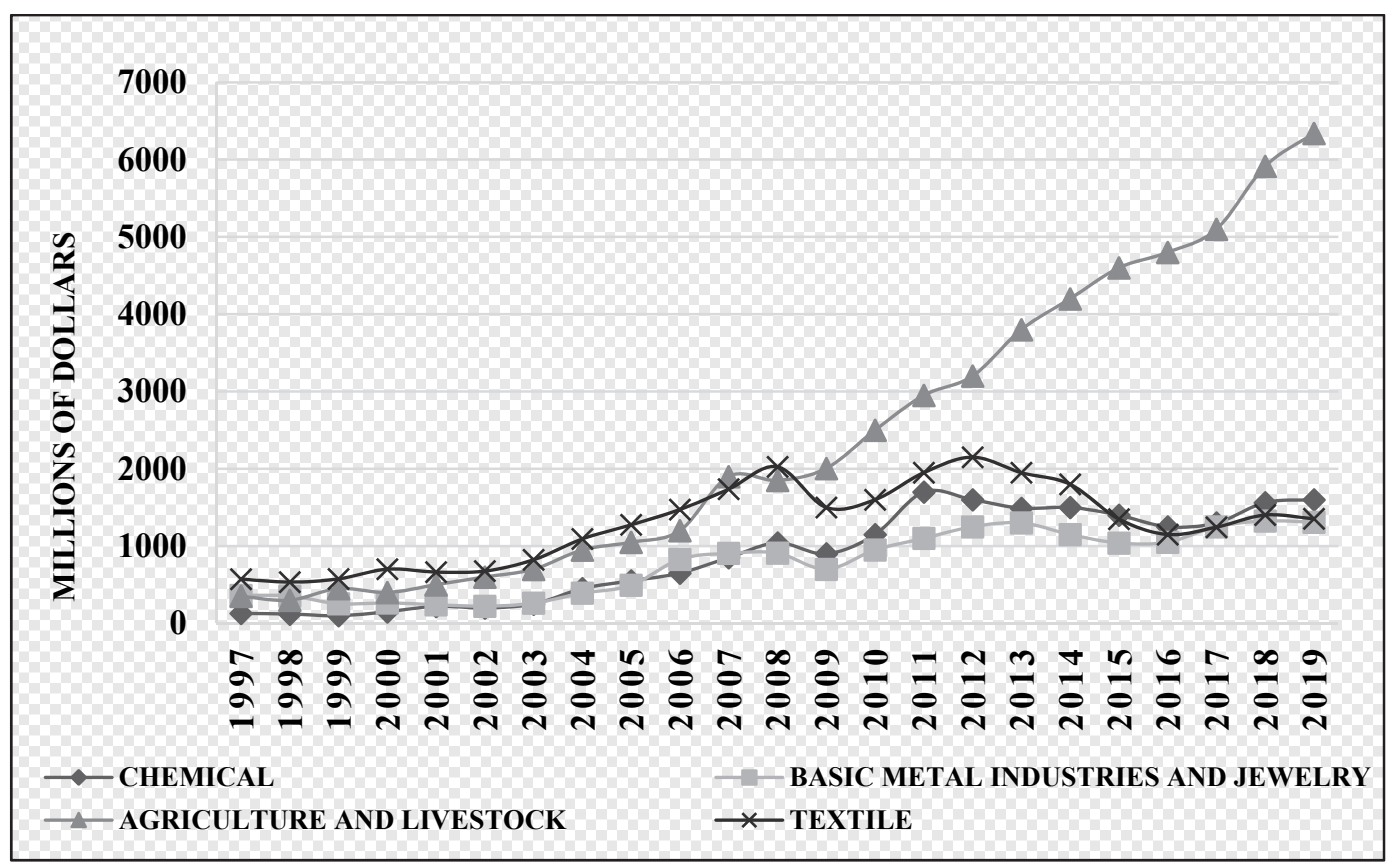

Figure 1. Peru: non-traditional exports 1997-2019 (millions of dollars)

Source: built by author based on Central Reserve Bank of Peru data. Retrieved December 102019 from https://www.bcrp.gob.pe/estadisticas/cuadros-de-la-nota-semanal.html

It is noted that in recent years, non-traditional exports have seen a wider inclusion of products in the exported supply, emphasizing a higher share of agricultural (43.5\%), chemical (11.8\%), textile (10.8\%), steel (9,8\%) and others. However, analyzing the overall Peruvian export matrix, it is noted that it remains focused on natural resources and low value-added products.

With regard to the above, the International Monetary Fund (2019) notes that exports from Andean countries are concentrated in the extractive sector, mainly in the oil and mining industries, which affects the rest of the exports, contributing to the strengthening of non-refundable exports with low productivity ("Dutch disease") and low competitiveness at the international level.

In this context, the identification of potential export goods in the framework of international trade will increase the production potential of the regions to meet the new global demand. In this regard, according to Rogers Valencia, Minister of Foreign Trade and Tourism, it is necessary to use 19 existing trade agreements signed by Peru, as trade unions allowed Peru preferential access to 55 countries and the market for more than 3,500 million consumers (see Figure 2).

In recent years, Peru, as part of a strategy to consolidate the income of its products in various markets, has begun negotiations on free trade agreements with countries with which it has had a wider trade exchange in order to seek higher permanent benefits for Peruvian products and take advantage of opportunities Expanded Market (MINCETUR, 2018).

In this order of issues, understanding the composition of Peruvian exports is important for analyzing potentials in various product groups. Between 2000 and 2019, Peruvian exports to the world increased six-fold, increasing from USD 6955 million to USD 47534 million over this period (Central Reserve Bank of Peru, 2020); 
however, the composition of the export basket has not changed significantly and shows that Peru is very dependent on the export of raw materials. In the period 2000-2019, it is noted that on average traditional exports accounted for $73 \%$ of total exports, which is similar to what was presented in 1997.

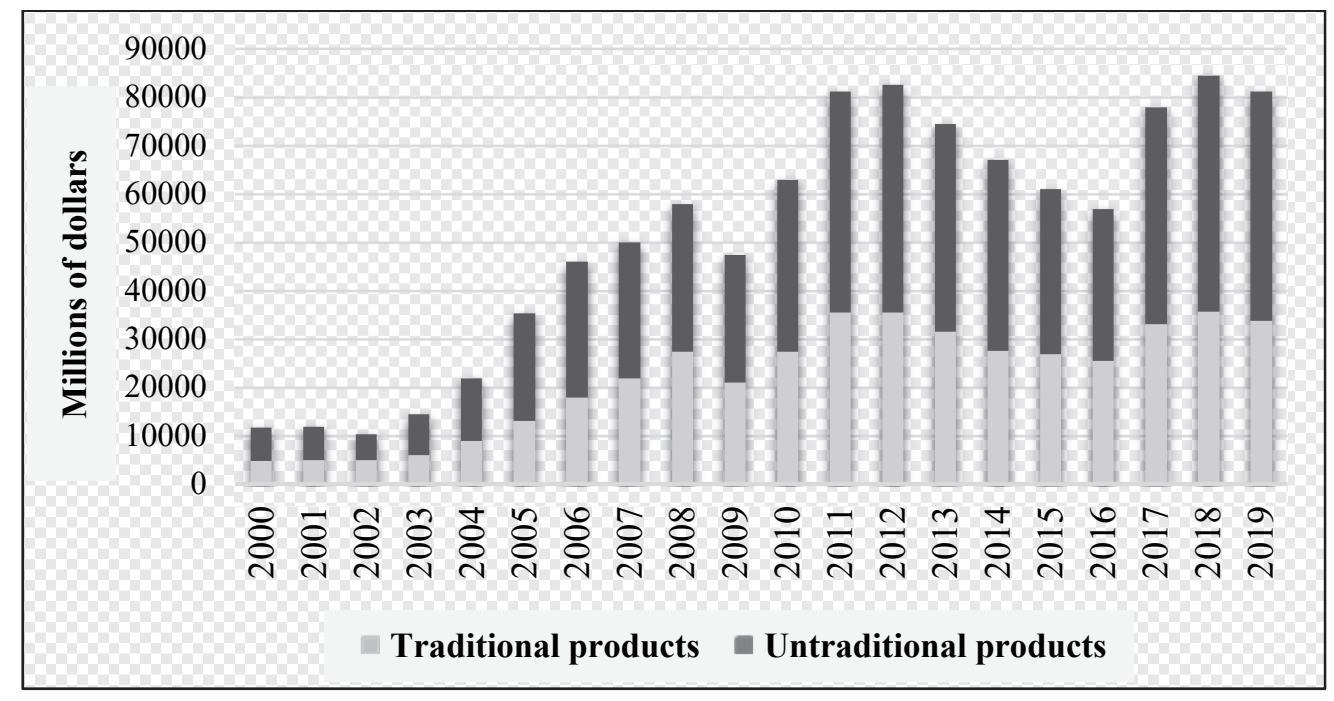

Figure 2. Peru: total exports 2000-2019 (millions of dollars)

Source: built by author based on Central Reserve Bank of Peru data. Retrieved December 102019 from https://www.bcrp.gob.pe/estadisticas/cuadros-de-la-nota-semanal.html

For Mendoza (2017), being Peru's primary export economy, the price of exports is the most important component of international conditions and the main determinant of terms of trade. In this regard, Peruvian exports followed the trends in the behavior of international markets. Thus, they indicate a fall of $-12.7 \%$ in 2009 , caused by the financial crisis in the United States, and a slowdown in the period 2012-2015, affected by lower prices for major exported goods, which was reflected in the cumulative fall of $18 \%$ of the terms of trade in the course of this period (Central Reserve Bank of Peru, 2016).

In 2018, a total of USD 27,159 million was recorded in foreign sales (Central Reserve Bank of Peru, 2018) of mining products, which accounted for $82 \%$ of the total volume of traditional products exported this year, compared to a lower share of oil and natural gas $(10 \%)$, fisheries $(5 \%)$ and agriculture $(2 \%)$. The share of mining products in the basket of export of raw materials has increased in recent years (in 2000 it was 67\%) compared with the gradual reduction in fish products (fishmeal), which in 2000 accounted for $20 \%$ of this group of goods.

Regarding target markets, based on 2019 information, four countries concentrated about $57 \%$ of Peruvian exports: $30 \%$ focused on the Chinese market, while the United States accounted for 16.6\%, Switzerland 5.3\% and the Republic of Korea $4.8 \%$ supplying Peruvian products. Other important markets are India (4.4\%), Japan (4.2\%) and Spain (4.2\%), among others (see Figure 3).

China is the main destination market for traditional exports, mainly mining $(38 \%)$ and fisheries (47\%); while the United States is the main destination for non-traditional exports, including textiles and clothing (50\%) and agribusiness (32\%) (MINCETUR, 2017). 
In addition, out of $88.7 \%$ of Peruvian exports, which were covered by preferences under the existing FTZs, the markets of China, the USA, the European Union, South Korea, the Andean Community, EFTA and Mercosur, among others, stand out.

Nevertheless, there is a concentration of deliveries abroad both in products and in markets; therefore, it is necessary to identify and stimulate new production activities, which are an additional factor in economic growth, which allows diversifying the export basket and integrating it into global value chains.
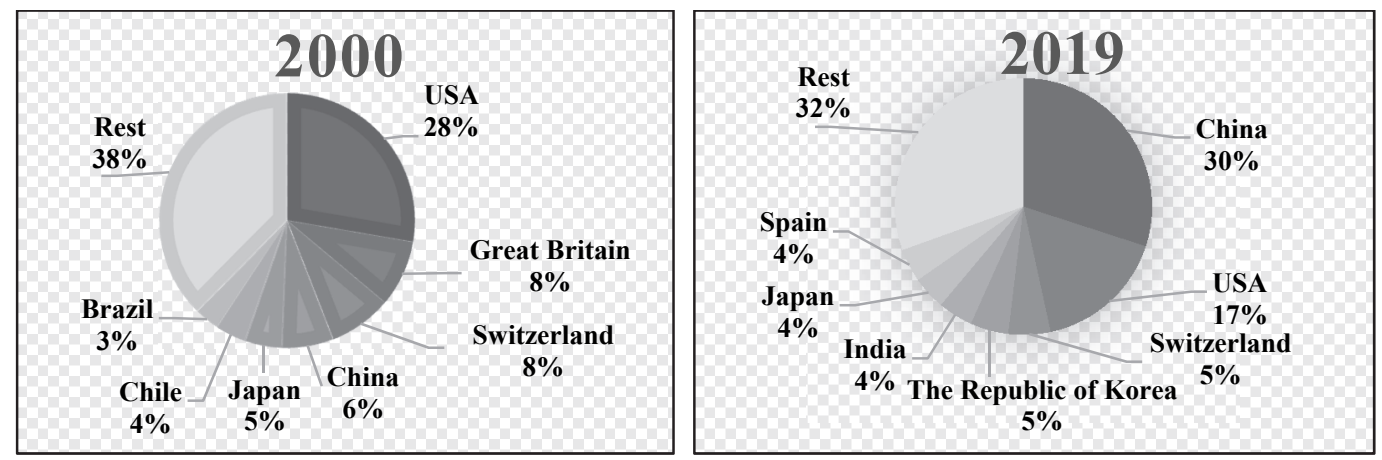

Figure 3. Peru: major export destinations, 2000 and 2019

Source: built by author based on SUNAT data. Retrieved December 152019 from http://www.sunat. gob.pe/operatividadaduanera/index.html

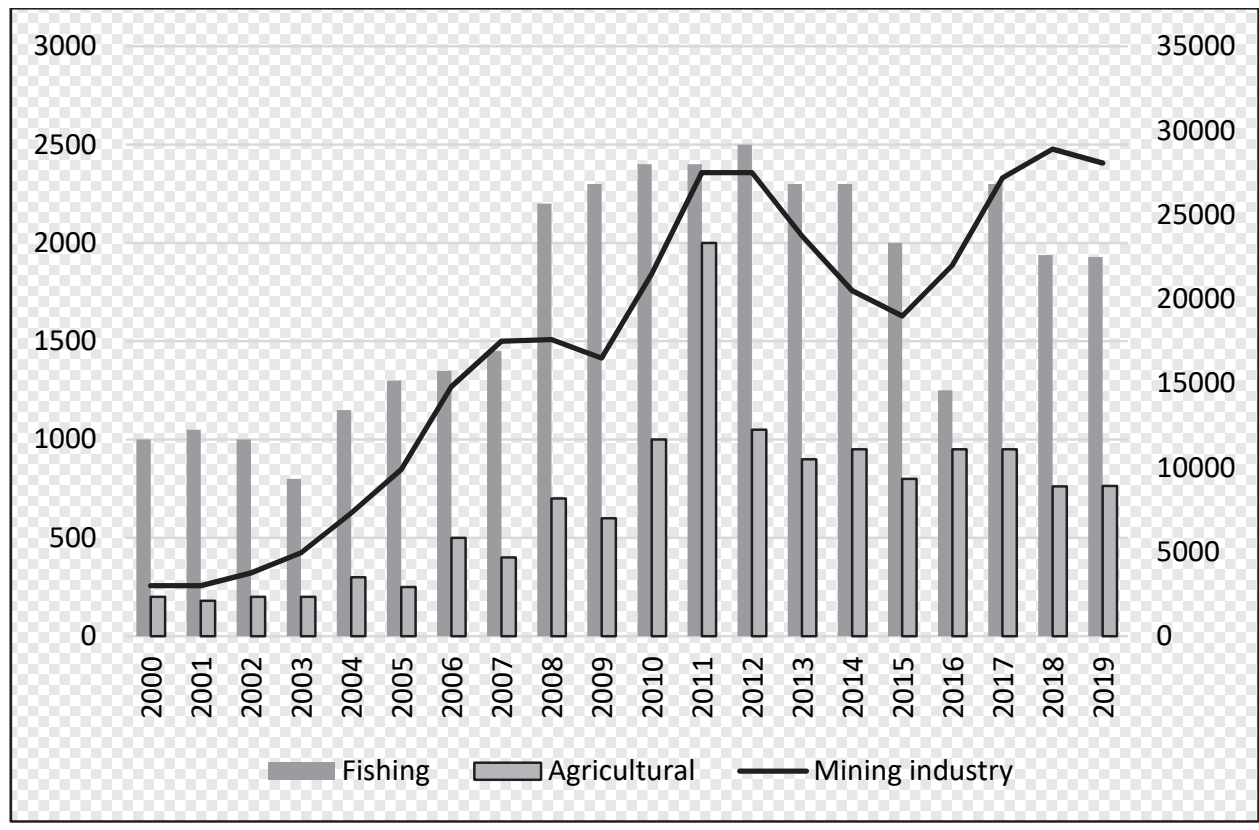

Figure 4. Peru: export of traditional products, 2000-2019 (millions of dollars)

Source: built by author based on Central Reserve Bank of Peru data. Retrieved December 102019 from https://www.bcrp.gob.pe/estadisticas/cuadros-de-la-nota-semanal.html

For Peñaranda (2017), international trade is a dynamic engine of economic activity, and its attractiveness lies in its ability to increase productive efficiency, as countries export goods that are relatively cheaper to manufacture and import products that are relatively expensive to produce. Regarding the analysis of ten free 
trade agreements signed by Peru, he concludes that the entry into force of these agreements enabled startups and diversification of the export basket with new products.

When breaking down large groups of goods, it can be noted that in 2000, the main exports of traditional goods, according to SUNAT, were gold and other types of raw materials (USD 1,144.2 million), fishmeal (\$ 874 million), minerals (zinc and their concentrates) (348.9 million USD), coffee (\$224.5 million) and minerals (copper) (\$ 140.5 million), including a significant increase by 2019.

The growth of the economies of China, India, and other emerging markets in Southeast Asia has led to an increase in demand for commodities in recent years amid further industrialization and urbanization of these countries. As a result of this increased demand in 2017 Peruvian exports of copper ores reached USD 11,999 million, gold in other unprocessed forms USD 7,096 million, and zinc ore USD 1,567 million, among the main products, with growth rates of about 8438 , 520 and $349 \%$ respectively, compared to 2000 year.

Regarding the export of unconventional products, in 2000 Peru registered sales totaling \$ 2,044 million (Central Reserve Bank of Peru, 2018), setting various products among the main deliveries, such as cotton shirts, asparagus, copper wire, thin cardan hair, cotton shirts, zinc alloys and lumber and others. Trade openness and the search for new markets allowed unconventional exports to reach $\$ 13,783$ million in 2019 (Central Reserve Bank of Peru, 2020), which represents a 674\% increase compared to 2000, mainly due to higher sales of agricultural products leading rating. The main exported Peruvian products are fresh grapes, avocados, asparagus, blueberries, calcium phosphate, mussels, mangoes, squid, among other products.
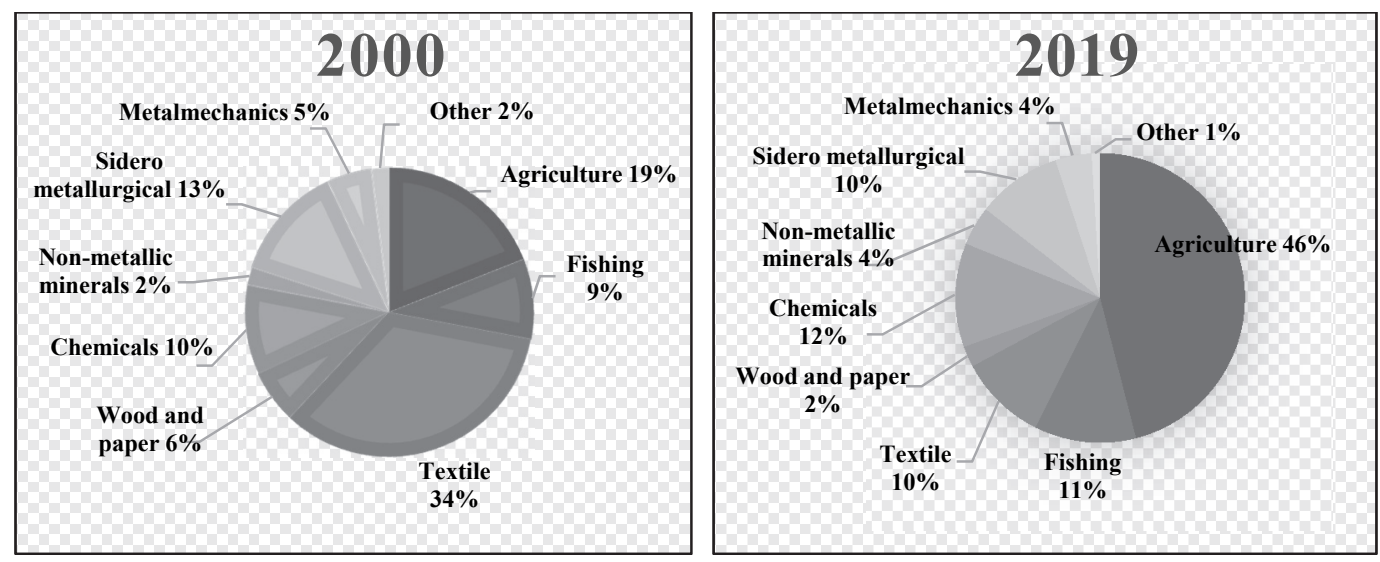

Figure 5. Peru: exports of major groups of unconventional products, 2000 and 2019

Source: Built by author based on Central Reserve Bank of Peru data. Retrieved December 052019 from https://www.bcrp.gob.pe/estadisticas/cuadros-de-la-nota-semanal.html

Products, that showed a greater presence on international markets from 2000 to 2019 are: (1) grapes, which gave a quantum leap from $\$ 5.9$ million in exports in 2000 to $\$ 882$ million in 2019; (2) avocados that have moved from export value from $\$ 2.5$ million to $\$ 731$ million; (3) asparagus from \$ 53.8 million to $\$ 398$ million; (4) animal feed from \$ 5.9 million to $\$ 225$ million; (5) mangoes from $\$ 23$ million to $\$ 241$ million; and others, such as blueberries, artichokes, or bananas, which in 2000 did not register commercial traffic, but which have been intensified in recent years. 
However, the international market is very wide and opens up opportunities for a larger share of Peruvian exports. Peru is involved with $34.2 \%$ of the world export of fishmeal; $20.5 \%$ in copper; $10 \%$ avocado; $7.8 \%$ of grapes; $7.4 \%$ of mangoes and mangosteen and, 2.8\% of gold, among other products (TradeMap, 2018).

These data indicate that there is room for further strengthening in the international market, and it is therefore imperative to work with regional manufacturers to take advantage of the benefits of various sectors, increase competitiveness and stimulate production chains so that local producers and enterprises could integrate at various stages of a specific production process in order to promote the socioeconomic development of the regions.

A relative specialization in the field of natural resources is required, as well as a sectoral policy of diversification of production, aimed not only to add value to potential sectors, but also to ensure that the country is productively developed and integrates small products.

In this context, based on information on international trade operations, the following are those products (traditional and non-traditional) in which Peru gained comparative advantages in the period 2010-2016 and which should continue to contribute to the diversification of the economy and the achievement of longer-term economic growth. Although the country has great potential that has not yet been fully utilized, there is a risk of losing significant progress if it stagnates or makes a mistake in continuing to export predominantly traditional products.

\section{Conclusion}

Thus, an analysis of international trade data based on comparative advantage indicators - the Balance of Trade and the Balassa Index - made it possible to determine a list of thirty products, of which twenty (traditional and non-traditional) increased in sales abroad, and the other ten, mostly unconventional, despite being lagging in the ranking, have greater potential for further growth.

1. Traditional products based on natural resources that Peru exported between 2010-2018 with a higher share in the trade in these products. This allows to get a positive BOT, which expresses an advantage on the trading exchanges. Among the products there are copper, gold, zinc, silver, lead, molybdenum, flour and fish oil, natural gas and coffee. It is necessary to take into account the regional strategy, which will make it possible to export products that are more complex, specialized, and various, to increase not only its competitiveness, but also make the economy less vulnerable to fluctuations in the prices of exported goods.

2. Non-traditional products with higher added value and exported to Peru with comparative advantages in the period 2010-2018. This group consists mainly of agroindustrial products, such as grapes, avocados, asparagus, blueberries, mangoes, bananas, cocoa, but also unsweetened zinc or evaporated milk, which represent a foreign trade dynamic that puts them with a positive BOT and significant export value in this group. This requires an increase in high logistics costs, high labor standards, a weak transport infrastructure, among other things, in order to distribute production factors necessary to create an industry with a high technological component.

3. Non-traditional products for restoring the export basket and targeting it to large global value chains. The following products were identified here: green peas, 
pomegranate, octopus, cocoa butter, woolen blankets or thin hair, woolen coats and sweaters, Pisco, onions, zinc and strawberry products. These products provide an opportunity to stimulate local development by strengthening production activities with export potential. Indeed, the national plan for diversifying production requires the creation of new growth mechanisms, identifying potentials from global value chains and coordinating efforts at the intersectoral and territorial levels to increase competitiveness.

The comparative advantages that the country has at the level of various types of products make it possible to continue to promote investments in these sectors and, in particular, to ensure regional development through productive rates that strengthen the business structure, the development of a competitive logistics infrastructure and supplier network, which may be included in the global value chain, which increases employment and well-being of the population.

In this regard, the following is an analysis of the endogenous capabilities of each region of the country (north, center and south), with more opportunities to meet the external demand for those products that can contribute to regional development. Departments with great potential for the development of the mining industry (in particular, Ankash, Arequipa, Junin), extraction of fish products (Ankash, Liberty, Piura and others), agricultural production (Piura, Liberty, Ica and others) or camel breeding (Puno, Junin, Cuzco), among other things, should open a discussion about regional productive development and how to help strengthen competitive potential.

Finally, it should be noted that the theoretical model by which this analysis is justified allowed to identify those leading goods in the export of goods at the national level; however, the export basket is wider and leaves room for international trade in other products with comparative advantages, such as jewelry, precious or semiprecious stones, seeded seeds, handmade paintings and drawings, styrene-polymer wastes and other identified products, showing positive Balance of Trade and Bilateral Balassa Index.

\section{References}

Central Reserve Bank of Peru. (2016). Inflation report: Current panorama and macroeconomic projections 2016-2018. Retrieved January 122020 from https://www.bcrp.gob.pe/ eng-docs/Monetary-Policy/Inflation-Report/2017/inflation-report-december-2017.pdf

Central Reserve Bank of Peru. (2018). Glossary of economic terms. Retrieved August 052019 from http://www.bcrp.gob.pe/publicaciones/glosario/e.html

Central Reserve Bank of Peru. (2018). Statistics Series. Central Reserve Bank of Peru. Retrieved August 052019 from https://estadisticas.bcrp.gob.pe/estadisticas/series/

Comtrade. (2018). UN Comtrade Database. Available at https://comtrade.un.org/

González, R. (2017). Export Competitiveness: A Theoretical Analysis Comparative Advantage Indicators and Their Application to Paraguay's Trade Data. Ministry of Finance of Paraguay.

Hausmann, R. (2014). Productive knowledge (DVD). CID Harvard. Retrieved November 30 2019 from https://www.youtube.com/watch?v=hqPIIV90X3Q

Helpman, E., \& Krugman P.R. (1985). Market Structure and Foreign Trade. Increasing Returns, Imperfect Competition, and the International Economy (p. 8). Cambridge, MA: MIT Press.

International Monetary Fund (IMF). Available at https://data.imf.org/?sk=388DFA60-1D264ADE-B505-A05A558D9A42

Lauterbach, R. (2015). Chile and the complexity of its exports. National Innovation Council for Development (CNID). Retrieved October 022019 from http://www.cnid.cl/wp- 
content/uploads/2015/11/FINAL_Chile-yla-complejidad-de-sus-exportaciones_Versi\% C3\%B3n-Final.pdf

Melitz M.J., \& Redding, S.J. (2014). Missing Gains from Trade? American Economic Review, 104(5), 317-321.

Melitz M.J., Mayer, T., \& Ottaviano, G. (2014). IP. Market Size, Competition, and the Product Mix of Exporters. American Economic Review, 104(2), 495-536.

MINCETUR. (2017). Monthly Foreign Trade Report. Retrieved December 052019 from https:// www.mincetur.gob.pe/wp-content/uploads/documentos/comercio_exterior/estadisticas_ y_publicaciones/estadisticas/exportaciones/2019/

MINCETUR. (2017). Regional Trade Report: Áncash. Retrieved November 152019 from https:// www.mincetur.gob.pe/wp-content/uploads/documentos/comercio_exterior/estadisticas_ y_publicaciones/estadisticas/reporte_regional/RRC_Ancash_2017.pdf

MINCETUR. (2018). 2019 Budget Support. Foreign Trade and Tourism Sector. Retrieved November 152019 from http://www.congreso.gob.pe/Docs/comisiones2018/Presupuesto/ files/m,_de_comercio_exterior.pdf

MINCETUR. (2018). Mango de Casma will reach international markets with the Quechua name Puquymi. Retrieved November 152019 from https://www.mincetur.gob.pe/minceturmango-de-casma-llegara-a-mercadosinternacionales-con-el-nombre-quechua-puquymi/

MINCETUR. (2018). PERU - US Commercial Promotion Agreement. Retrieved November 15 2019 from http://www.acuerdoscomerciales. gob.pe/index.php?option=com_content\& view $=$ category $\&$ layout $=$ blog $\&$ id $=55 \&$ Itemid $=78$

National Customs Superintendency and Tax Administration (SUNAT). Available at http://www. sunat.gob.pe/operatividadaduanera/index.html

Peruvian National Center for Strategic Planning (CEPLAN). Available at https://www.ceplan.gob.pe/

Peruvian National Institute of Statistics and Informatics (INEI). Available at https://www.inei.gob.pe/

The Global Competitiveness Report. (2018). Available at https://www.weforum.org/reports/ the-global-competitveness-report-2018

The Organisation for Economic Co-operation and Development (OECD). Available at http:// www.oecd.org/countries/peru/

TradeMap. (2018). Trade statistics for international business development. Retrieved July 20 2019 from https://www.trademap.org/countrymap/Country_SelProduct_TS.aspx

World Bank Data. Available at https://data.worldbank.org/

World Trade Organization. (2018). Merchandise Trade: the Pacific Alliance. Retrieved November 292019 from https://www.wto.org/english/res_e/statis_e/reports_newsletters_e.htm

Article history:

Received: 30 December 2019

Revised: 25 January 2020

Accepted: 23 February 2020

Zhilkin, O.N., \& Chavarry Galvez, W.P. (2020). Analysis of current trends in assessing the country's potential in international trade (on example of Peru). RUDN Journal of Economics, 28(2), 239-253. http://dx.doi.org/10.22363/2313-2329-2020-28-2-239-253

\section{Bio notes:}

Oleg N. Zhilkin, Candidate of Science (in Economics), Associate Professor of the Economical \& Mathematical Simulation Department, Peoples' Friendship University of Russia (RUDN University). E-mail: zhilkin-on@rudn.ru

Wilmer Paul Chavarry Galvez, PhD student, Peoples' Friendship University of Russia (RUDN University). E-mail: wilmerchg14@gmail.com 


\title{
Анализ современных тенденций оценки потенциала страны в международной торговле (на примере Перу)
}

\author{
О.Н. Жилкин, В.П. Чаварри Гальвес \\ Российский университет дружбы народов \\ Российская Федераџия, 117198, Москва, ул. Миклухо-Маклая, 6
}

В статье рассматриваются вопросы теории международной торговли, основные современные глобальные тенденции оценки возможностей развития внешнеэкономического сектора экономики стран Латинской Америки в целом и Перу в частности. Используя статистические данные о развитии внешнеторгового сектора с учетом глобальных тенденций в международной торговле за последнее десятилетие, предпринята попытка получить представление о способностях стран Латинской Америки удовлетворять растущий дифференцированный спрос и таким образом специализироваться на том, что имеет сравнительные преимущества, дает им возможность интегрироваться в глобальные производственно-сбытовые цепочки посредством предоставления ресурсов, промежуточного продукта или интеграции в цепочку поставок с собственным конечным продуктом. Изучение потенциальных возможностей стран Латинской Америки способствует созданию производственно-сбытовых цепочек вокруг рыночных ниш, существующих в глобальной торговле, и их применению для получения латиноамериканскими продуктами международного признания. В этом контексте анализ динамики торгового обмена берется в качестве основы для сравнения Перу с другими странами, так как, по данным МВФ, в последние годы Перу является одной из стран с прогнозом наибольшего экономического роста в Латинской Америке. Перу обладает высокой способностью к развитию горнодобывающей промышленности (Анкаш, Арекипа, Хунин), добычи рыбных продуктов (Анкаш, Либерти, Пьюра и др.), агропромышленного производства (Пьюра, Либерти, Ика и др.), разведению верблюдов (Пуно, Хунин, Куско) и прочих видов деятельности. В 2018 г. Перу удалось поднять общий экспорт до 47709 млн долл. США (+7.5\% по сравнению с 2017 г.), достигнув исторического рекорда в перуанском экспорте. Этот рост объясняется заметным прогрессом нетрадиционного сектора, который достиг 13223 млн долл. США (+12,6\% по сравнению с 2017 г.). В настоящем исследовании использовалась теория сравнительных преимуществ для количественной оценки конкурентоспособности продукта на основе глобального сравнения, что способствует пониманию того, как продвигаться к более высоким уровням специализации в производственной и экспортной структуpax. Для анализа данных о международной торговле применялись такие показатели, как индекс торгового баланса и индекс Баласса, позволившие определить список из тридцати продуктов, среди которых двадцать (традиционных и нетрадиционных) показали уверенный рост экспорта, а другие десять, в основном нетрадиционные, несмотря на то что являются в рейтинге отстающими, имеют больший потенциал для дальнейшего роста.

Ключевые слова: международная торговля, сравнительные преимущества, экспорт, Латинская Америка

\section{История статьи:}

Дата поступления в редакцию: 30 декабря 2019

Дата проверки: 25 января 2020

Дата принятия к печати: 23 февраля 2020 


\section{Для цитирования:}

Zhilkin O.N., Chavarry Galvez W.P. Analysis of current trends in assessing the country's potential in international trade (on example of Peru) (Анализ современных тенденций оценки потенциала страны в международной торговле (на примере Перу)) // Вестник Российского университета дружбы народов. Серия: Экономика. 2020. Т. 28. № 2. C. 239-253. http://dx.doi.org/10.22363/2313-2329-2020-28-2-239-253

\section{Сведения об авторах:}

Жилкин Олег Николаевич, кандидат экономических наук, доцент кафедры экономикоматематического моделирования Российского университета дружбы народов. E-mail: zhilkin-on@rudn.ru

Чаварри Гальвес Вильмер Пауль, аспирант Российского университета дружбы народов. E-mail: wilmerchg14@gmail.com 